\title{
Erratum: Localization in Flow of Non-Newtonian Fluids Through Disordered Porous Media
}

\author{
Frontiers Production Office* \\ Frontiers Media SA, Lausanne, Switzerland
}

\section{OPEN ACCESS}

Approved by: Frontiers Editorial Office, Frontiers Media SA, Switzerland

*Correspondence: Frontiers Production Office production.office@frontiersin.org

Specialty section:

This article was submitted to Interdisciplinary Physics, a section of the journal

Frontiers in Physics

Received: 22 July 2021 Accepted: 22 July 2021

Published: 12 August 2021

Citation:

Frontiers Production Office (2021) Erratum: Localization in Flow of NonNewtonian Fluids Through Disordered

Porous Media.

Front. Phys. 9:745605

doi: $10.3389 /$ fphy.2021.745605
Keywords: microfluidics, particle velocimetry, non-Newtonian fluids, localization, porous media

\section{An erratum on}

Localization in Flow of Non-Newtonian Fluids Through Disordered Porous Media by Seybold, H. J., Eberhard, U., Secchi, E., Cisne, R. L. C., Jiménez-Martínez, J., Andrade, R. F. S., Araújo, A. D., Holzner, M., and Andrade, J. (2021). Front. Phys. 9:635051. doi: 10.3389/fphy.2021. 635051

Due to a typesetting error, the brackets around $\dot{\gamma}$ were incorrect in Eq. 4. This error appears in the HTML, XML, and EPUB versions of this article. The correct version is shown below. The publisher apologizes for this mistake.

The original HTML, XML, and EPUB of this article has been updated.

$$
\mu_{C}(\dot{\gamma})=\mu_{\infty}+\frac{\left(\mu_{0}-\mu_{\infty}\right)}{\left.\left(1+[\lambda \dot{\gamma})^{2}\right]\right)^{\frac{1-n}{2}}}
$$

Copyright (c) 2021 Frontiers Production Office. This is an open-access article distributed under the terms of the Creative Commons Attribution License (CC BY). The use, distribution or reproduction in other forums is permitted, provided the original author(s) and the copyright owner(s) are credited and that the original publication in this journal is cited, in accordance with accepted academic practice. No use, distribution or reproduction is permitted which does not comply with these terms. 